\title{
Experiências a/r/tográficas: gênero e sexualidades
}

\section{LUCIANA BORRE NUNES}

\section{Resumo}

Texto poético e narrativo. Conta histórias pessoais que provocaram processos - intencionais e pretensiosos - de aprender e ensinar no campo das artes visuais. Escrita por um grupo produtor de imagens que através de leituras, diálogos e experimentações/imersões poéticas buscou caminhos para pensar a produção de gênero, sexualidades e cultura visual. Um viés a/r/tográfico inundou nossas práticas pedagógicas tramando esta escrita coletiva que confunde a autoria e

Palavras-chave: Cultura visual, a/r/tografia, gênero e sexualidades denuncia memórias. Procura nos relatos de situações cotidianas a potência de uma formação docente em Artes Visuais baseada nos atos de aprender, pesquisar, artistar e ensinar. 


\section{A/r/tografhic experiences: gender and sexuality}

\begin{abstract}
A poetic and narrative text. It tells personal stories that led to intentional and pretentious processes of teaching and learning in the field of visual arts. It is written by a group of producers of images and that through lectures, dialogues and poetic immersion, has sought to think about gender identities, sexualities and visual culture. An a/r/tografhic field provides the basis for our teaching practices and provides the possibility of a collective writing that confuses the authorship, denouncing our memories. The review of texts grounded on the everyday situations demonstrated the power of a Visual Arts teacher training that is based on the acts of learning, researching, being an artist, and teaching visual arts.
\end{abstract}

Keywords:

Visual culture, a/r/tografh, gender and sexuality 


\section{Experiencias a/r/tográficas: género y sexualidades}

LUCIANA BORRE NUNES

\section{Resumen}

Texto poético y narrativo. Cuenta historias personales que estimulan procesos -intencionales y pretenciosos - de aprender y enseñar en el campo del arte visual. Escrita por un grupo productor de imágenes que a través de lecturas, diálogos y experiencias/ inmersiones poéticas buscó caminos para pensar la producción de género, sexualidades y cultura visual. Una oblicuidad $\mathrm{a} / \mathrm{r} /$ tográfica inundó nuestras prácticas pedagógicas, tejiendo este escrito colectivo que confunde autoría y denuncia de memorias. Busca en género y sexualidades los relatos de situaciones cotidianas la potencia de una formación docente en Artes Visuales basada en los actos de aprender, investigar, artistar y enseñar. 
CUIDADO! Este texto:

(1) possui conteúdo autobiográfico e de fácil identificação;

(2) contém fatos/imagens/pensamentos verídicos (da vida real);

(3) está escrito em primeira pessoa.

Eu tramava imaginários e poéticas do corpo performatizado. Tu tramaste rituais sobre como viver o feminino. Ela me jogou na trama feminista e depois me abandonou em novas verdades. Ele entendeu que as formas de poder disciplinam e, assim, confiou nos movimentos sociais minoritários. Nós tramaremos bagunças no ato de pesquisar e vós apontareis os marcadores sociais da diferença: sexualidades, corpo, raça, etnia, classe social (...). Eles buscarão a liquidez dos discursos queer e, voltarão ao aprisionamento. Elas, acreditando-se emancipadas, consolidarão novos contextos de cidadania sexual e afetiva.

Um emaranhado de vozes e tempos ecoará no desenvolvimento desse texto que se pretende poético e narrativo. Histórias pessoais provocaram processos (intencionais e pretensiosos) de aprender e ensinar no campo das artes visuais enquanto o grupo se constituiu como produtor de imagens. Leituras, diálogos e experimentações/imersões poéticas compuseram os caminhos para pensarmos a produção de gênero e sexualidades através da cultura visual. Esperamos que um viés a/r/tográfico possa inundar as práticas de pesquisar, ensinar e artistar.

Tramamos uma escrita coletiva que confunde autoria, denunciando-nos. Giselle, Jaci, Luana, eu (Luciana) e Rafael protagonizamos a produção de imagens e poéticas visuais com a intenção de subverter/romper/desconfigurar/recriar 
"Divindades Femininas", Aquarelas, Giselle Silva, 2015.
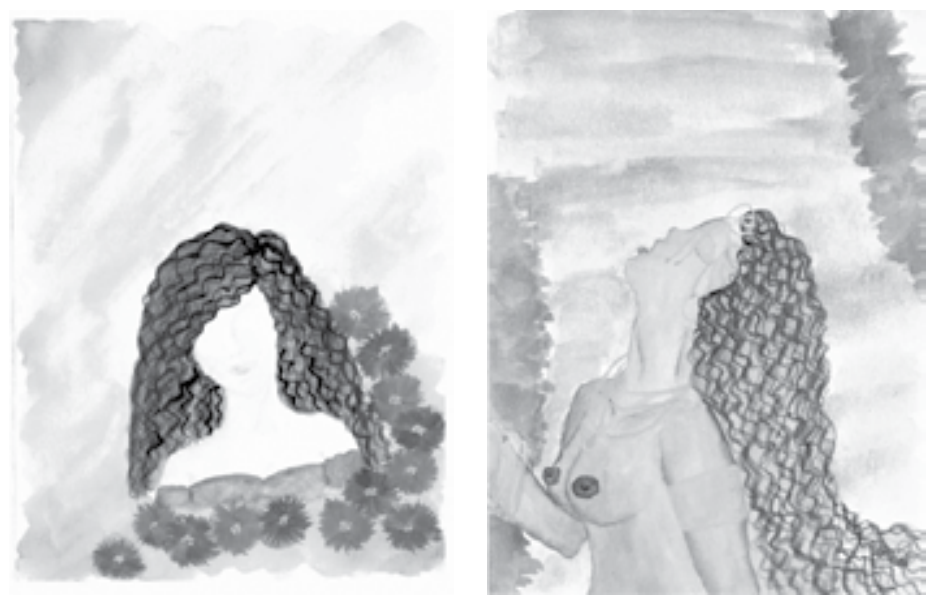

discursos naturalizados sobre como viver gênero e sexualidades. Procuramos nos relatos de situações cotidianas a potência de uma formação docente em artes visuais baseada nos atos de aprender, pesquisar, artistar e ensinar. Eis que histórias de vida - amores, dores, frustrações e sorrisos - desencadearam processos reflexivos sobre educação da cultura visual durante a disciplina de metodologia do ensino das artes visuais, no curso de artes visuais da Universidade Federal de Pernambuco (UFPE), em 2015.

\section{Divindades femininas - Giselle Silva}

Saí de casa vestida toda de branco. Estava com uma saia rodada (acho saias desse tipo um charme), uma blusinha de algodão e chinelo de couro. Chegando à parada de ônibus avistei uma senhora do outro lado da rua. Senti a intensidade do seu olhar. Ela veio em minha direção achei um pouco estranho e pensei que, talvez, pudesse conhecê-la - e o inesperado aconteceu. Parou na minha frente e começou a gritar: "Deus tá vendo o que você anda fazendo, viu?! Coisa ruim! Vai pros teus xangôs, vai!” Ela pegou um fio de poste (molhado) caído no chão, sacodiu em minha direção e foi embora com uma expressão de raiva. Fiquei sem reação no momento, vendo somente que todos voltaram seus olhares para a cena. Ao embarcar no ônibus, um turbilhão de sentimentos e pensamentos tomou conta de mim. Relembrei de outro dia, no metrô, quando uma pessoa disse em voz alta: "tem pente em casa 
não, é?!" Mesmo não sendo adepta a religiões afro-brasileiras essas situações mexeram muito comigo. Se meu cabelo crespo e roupas brancas incomodam, o que as pessoas negras, mulheres e adeptos das religiões afro sofrem?

\section{Corte com/tensão - Jaci Borba}

Estou num ônibus indo pra Casa Forte/Recife. Um ônibus vazio exceto pela óbvia presença de uma pessoa que dirige o veículo e outra que recolhe os pagamentos. Nenhuma preocupação me ocorre a não ser a atenção extrema para não perder o ponto de descida. Olhos fixos na janela. Sobem dois homens que cumprimentam os outros dois homens. Os recém-chegados não me veem até que, finalmente, me levanto para acionar o sinal de descer. Eu, com calça jeans e cabelo cortado (curtinho como eu queria), tênis, camiseta e portando uma mochila. Eles, com um alto nível de ódio e preconceito. Ao descer, um dos homens põe a cabeça na janela do ônibus e começa a me insultar. É tudo muito rápido, o semáforo fecha, as pessoas na rua olham apáticas e talvez felizes pela quebra da rotina nessa tarde. $\mathrm{O}$ homem esbravejava, cuspia seu veneno e me banhava com saliva fétida. Paralisou meus nervos, emudecendo-me: "Machinho! Vem saber o que é homem! Olha o tamanho dela, só o meu 'pau' é do teu tamanho! É que ninguém 'comeu' direito!” Paralisada, não consegui atravessar a rua e seguir meu rumo. Foi tudo tão rápido, mas era como se ainda estivesse acontecendo em um tipo de slow motion. Quem disse que sou lésbica? Quem disse que se eu fosse lésbica ele teria o direito de me agredir? Quem disse? Quem deu esse direito? A homofobia me atingiu, machucando-me.

\section{Pequenas agressões - Luana Andrade}

Eu sempre pensei que amamentar fosse automático e natural. Nasceu o filho, amamento-o. Contudo, devido a todas as dificuldades físicas inerentes à amamentação - a dor, o mamilo plano e a inexperiência - não consegui amamentar o meu primeiro filho. Carreguei culpa por isso. Todas as viroses, cólicas e desapegos, em meu (in)consciente, só tinham 


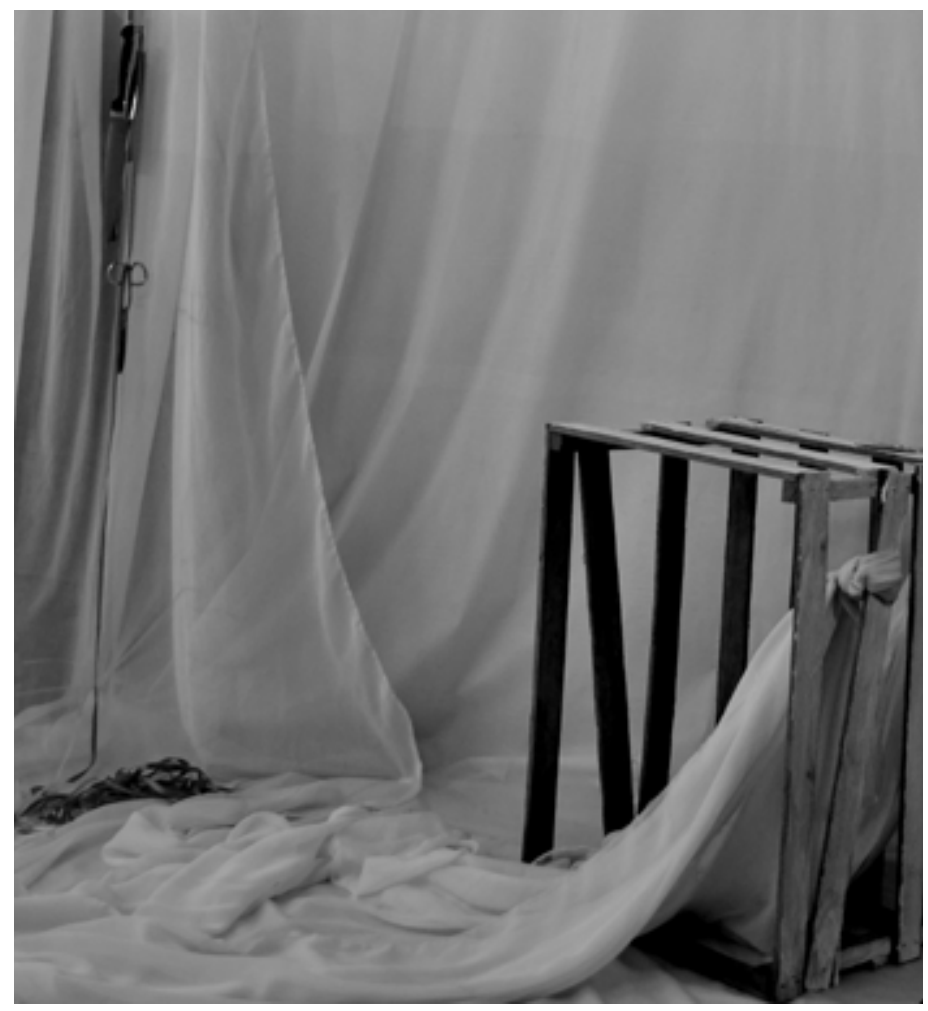

uma razão: a incompetência de não amamentar. Um fracasso! Na minha segunda gravidez prometi que iria ser diferente. Pesquisei, fiz exercícios de estímulo nos mamilos, comprei acessórios e remédios. Ela nasceu. Tinha que dar certo... E deu! Tinha leite igual 'vaca holandesa'. Alimentava minha filha e me sentia competente e completa na arte de ser mãe. Um orgulho danado até o dia que precisei amamentar na rua. Estava na praça e precisei cobrir tudo porque um homem ficou me olhando 'estranho'. Depois, uma criança que passava falou: "olha, mãe, um bebê!" Eu, toda orgulhosa, descobri minha filha e meus seios e, imediatamente, a zelosa esposa afastou o marido e o filho daquela devassa que se expunha na rua. Passei por situações parecidas outras tantas vezes. Algumas mulheres sugeriram que me escondesse para amamentar. Um dia me peguei dando leite artificial a minha filha para não expor meu seio ao meu orientador na universidade, com receio de ofendê-lo. Depois disso tudo, percebi que a dor de amamentar é muito mais moral que física. 

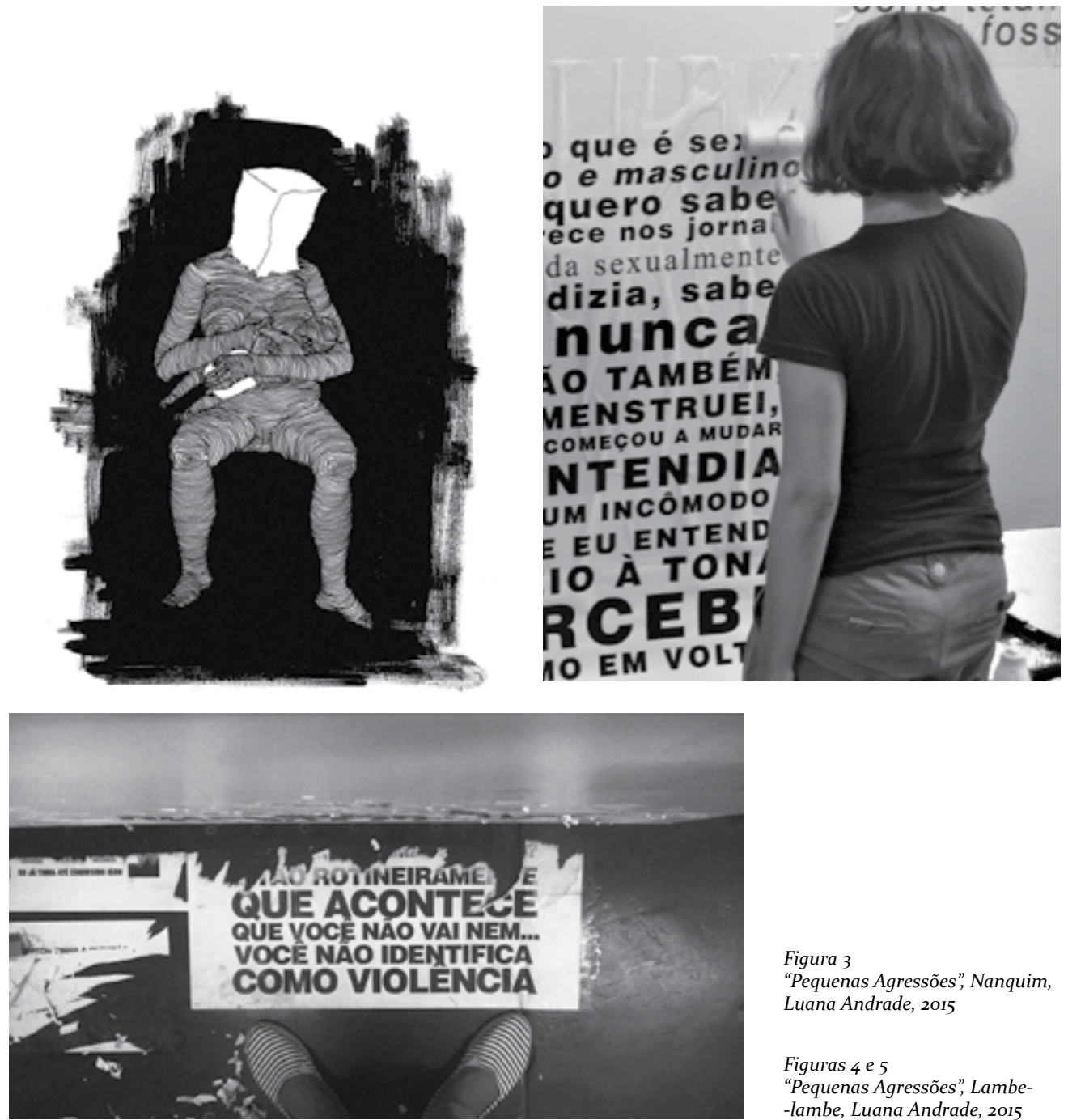

Figura 3

"Pequenas Agressões", Nanquim, Luana Andrade, 2015

Figuras 4 e 5

“Pequenas Agressões”, Lambe-lambe, Luana Andrade, 2015

\section{Tramações - Luciana Borre}

Aconteceu durante uma confraternização familiar. Estávamos reunidos em volta de uma mesa para comemorarmos a colação de grau do meu irmão. Durante as preces, uma das minhas tias pediu a palavra e fez uma oração. Ela pediu a Deus que eu finalmente conseguisse um bom namorado para se constituir meu futuro marido. Diante do silêncio de todos e dos olhares de concordância e benevolência, cheguei a acreditar que eu era uma infortunada por ainda não ter casado. Compartilhei aquela 
intenção e, naquele momento, fiquei satisfeita porque todos estavam rezando por mim, pelo meu possível futuro casamento. Durante a infância estive imersa em uma rede de contos de fadas, histórias de princesas, ensinamentos religiosos, crenças familiares e rodas de conversa que consolidavam a felicidade feminina atrelada ao casamento. São discursos que se tornaram naturalizados em meu cotidiano e que consolidaram versões de realidade nas quais acreditei que "toda mulher tem o sonho de casar", que "todas nascem com instituto materno" e que o casamento, muitas vezes, é sinônimo de "viveram feliz para sempre".

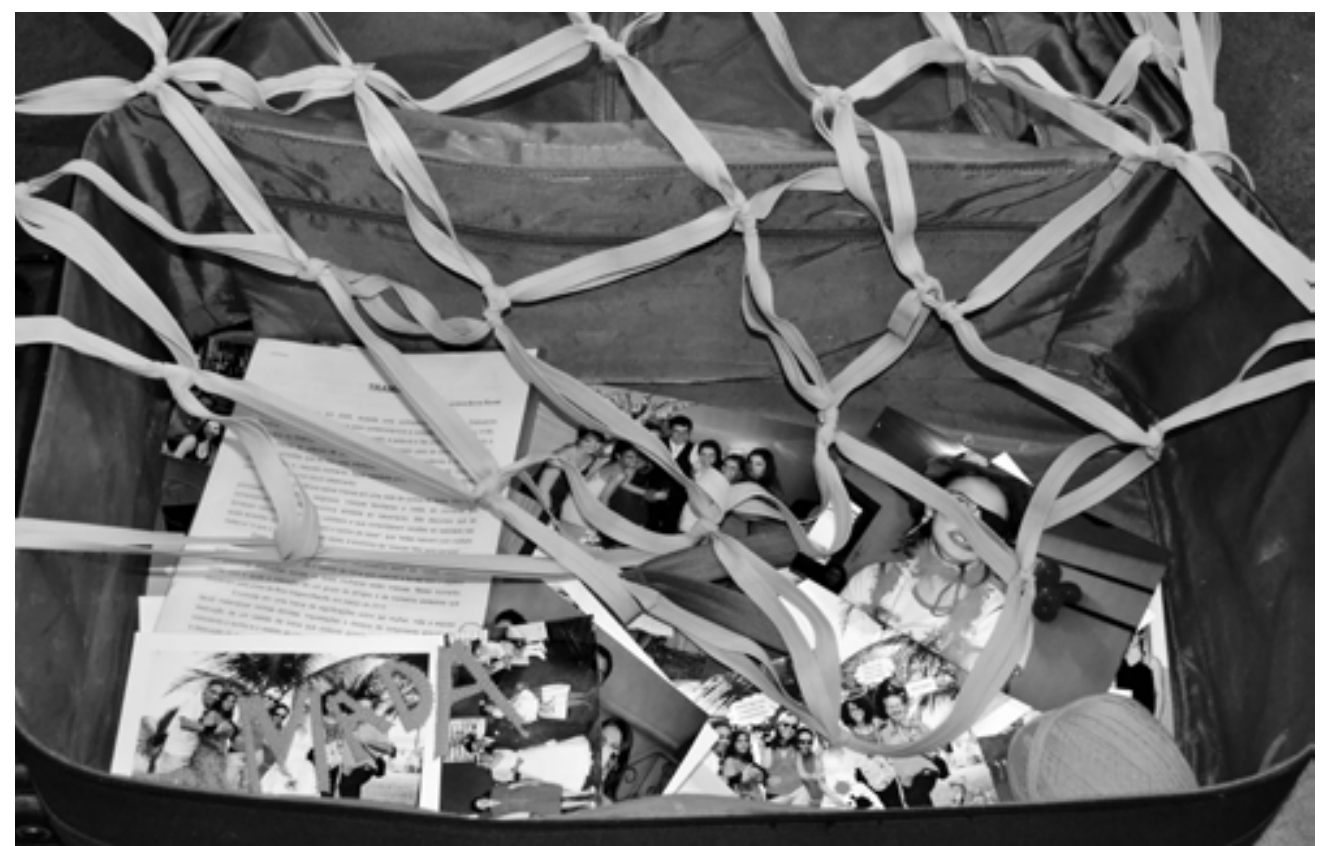

Figura 6

“Tramações”, Instalação, Luciana Borre, 2015
Instrumento humano indispensável - Rafael Vascon

O reconhecimento do "outro" como semelhante é um processo de aceitação das diversas identidades e da pluralidade de experiências humanas. Os muros físicos e simbólicos, assim como os murais das redes sociais em que o ódio e os diversos preconceitos são abertamente confessados, foram traduzidos numa experiência de reflexão, cuja síntese seja, talvez, a construção de uma sociedade mais justa e participativa. 


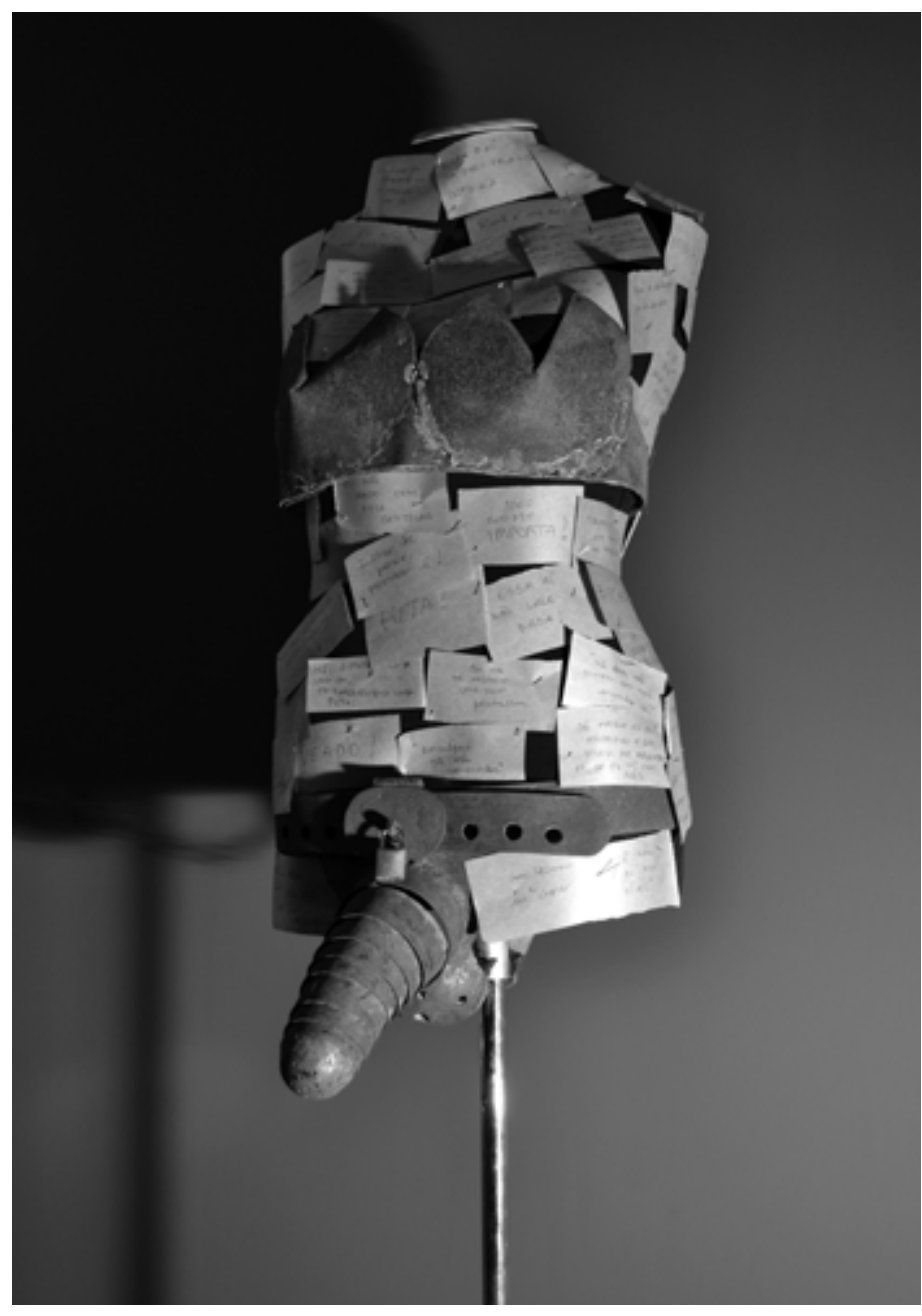

\section{Aprendemos, ensinamos, pesquisamos e artistamos}

A turma de metodologia do ensino das artes visuais era composta por 20 estudantes que tinham diante de si uma proposta de experimentações a/r/tográficas e debates no campo da cultura visual. A/r/tografia produz sentidos sobre ser: Artist (artista), Researcher (pesquisador), Teacher (professor) e grafh (grafia: escrita/representação) (DIAS, 2013, p. 25). A intenção, pretensiosa e duvidosa, era contar e compartilhar histórias relatos de vida - que ressignificassem recordações íntimas e
Figura 7

"Instrumento Humano Indispensável", Escultura,

Rafael Vascon, 2015 
subjetivas, expandindo-as para discussões sobre a construção social de nossas visualidades.

Neste caminho, buscamos uma formação docente baseada na reflexão crítica de ações educativas, na produção de poéticas visuais e no aprofundamento teórico sobre práticas de pesquisa, pois "a docência é uma prática atrelada à pesquisa e, ao mesmo tempo, de que a pesquisa é uma prática que fundamenta, organiza e renova a docência" (TOURINHO, 2013, p. 64).

Ao final da disciplina estávamos submersos na exposição "Experiências A/r/tográficas", que aconteceu nos dias 23, 24 e 25 de novembro de 2015, no hall do Centro de Artes e Comunicação da UFPE, na qual Giselle, Jaci, Luana, eu (Luciana) e Rafael discutimos e escrevemos sobre diferentes tópicos dentro das questões de gênero e sexualidades. A interação com colegas, professoras/es e comunidade acadêmica durante a exposição demonstrou que nossos vídeos arte, instalações, desenhos e intervenções provocavam questionamentos, incompreensões - algumas rejeições - desejos de participação e empatia nos visitantes. Voltamos para sala de aula com muitas perguntas e entendemos que a proposta $\mathrm{a} / \mathrm{r} /$ tográfica favoreceu um encontro de experiências, produção de sentidos e, até mesmo, risco de consolidação de novas verdades.

Ao propor um vídeo arte e uma instalação com tesouras afiadas e facas pontiagudas Jaci (Corte Com/Tensão) buscou respostas, principalmente sobre aquela parte "que não conseguiu atravessar a rua". Ela ainda dialogou com autores, permitiu-se duvidar de suas perspectivas, escutou o relato de outras mulheres e protagonizou a produção de imagens:

Esta experiência a/r/tográfica somou-se à busca pela expressão do "não dito" que me habita radicalmente. É sobre aquilo que não sei dizer sobre as outras mulheres, mas reconheço em mim. É sobre o humano, sobre-humano, e que só posso dizer com firmeza do meu lugar de mulher. Mulher? Lugar de mulher? Lugar de fala? O que me roubou a fala é o meu grito de hoje, mesmo que abafado pelas pequenas agressões diárias de antes, de hoje e das que virão. Assim como Eça (2013, p. 73), acredito que durante uma investigação "muitas perguntas se podem fazer e muitas maneiras de ir para além das perguntas, gerando outras em um espírito de indagação contínuo que nunca se poderá dar por encerrado". Notei que a minha roupa e o 
meu corte de cabelo foram postos como estereótipos alvo para o agressor e, na busca por respostas e novas provocações, lancei-me a pesquisar tendo um questionamento: como roupas definem gênero e sexualidades e como estas definições geram violência? Isto foi sobre mim, mas não era a única. Durante a produção de "Corte com/tensão" conversei com amigas, observei comportamentos de algumas mulheres que circulavam no meu cotidiano, fiz leituras e percebi uma gama de imagens que me deram recursos para a inconclusão proposta na obra. Fui contagiada e "essas contaminações geram diálogos com a diversidade através de apropriações, interferências, marginalizações e, até mesmo, silêncios, produzindo espaços onde novos objetos e imagens podem influenciar imaginários sociais e subjetividades individuais" (MARTINS, 2013, p. 85). Um vídeo arte exibido no hall do Centro de Artes e Comunicação (CAC-UFPE) compôs uma cena sem a pretensão de explicar coisas, mas problematizar alguns fatos sobre ser mulher nesse tempo, nesse lugar, fruto de uma pesquisa viva partindo da experiência.

Entender como acontece a formação de professoras/es para questões de gênero e sexualidades é uma inquietude que transpassa minhas práticas como professora: quais embates, enfrentamentos e possibilidades que professoras/es de artes visuais encontram em relação a questões de gênero e sexualidades no âmbito formal e não formal de ensino? Como acontece o processo de formação de professoras/es de artes visuais sobre questões de gênero e sexualidades? Como um grupo de alunas/os do curso de Artes Visuais da UFPE entendem questões de gênero e sexualidades em seu processo de formação profissional?

Como docente no âmbito acadêmico percebi que questões de gênero e sexualidades circulavam os interesses das/os estudantes e que a cultura visual "concentra atenção especial nos fenômenos (não apenas) visuais que estão acontecendo hoje, na utilização social, afetiva e político-ideológica das imagens e nas práticas culturais e educativas que emergem do uso dessas imagens" (MARTINS, TOURINHO, 2015, p. 141).

Luana é uma destas estudantes que atuava como professora de artes visuais em âmbito não formal de ensino e que procurava espaço para debater e expor seus enfrentamentos pessoais. "Pequenas Agressões” (técnicas de lambe-lambe e nanquim) com frases/revelações da irmã, amigas e conhecidas constituíram a 
matéria-prima para sua produção poética. Sobre suas motivações Luana comentou que...

a ideia de abordar a violência de gênero veio das conversas que tive com minha irmã, mãe de dois filhos. Os depoimentos dela foram um pontapé pra que eu decidisse fazer “Pequenas Agressões”. As questões de gênero e violência já me transpassavam e há algum tempo que todas as minhas produções (imagens e textos) se vinculavam a isso. Quando eu decidi usar a fala dela como material na minha experiência a/r/tográfica pedi que ela escrevesse sua história sobre a amamentação. Eu a vi sentar-se à mesa (mais ou menos meia-noite, quando os filhos já estavam dormindo), escrever, reler algumas vezes e entregar esse depoimento depois de refletir sobre seu cotidiano normatizado. Esse relato é um grifo da sua trajetória como gente, mulher e mãe, destacado pelo caráter de denúncia e pela necessidade do grito.

Os três "cuidados" descritos na abertura deste artigo foram elencados por Luana e transmitidos aos visitantes da exposição. Ao advertir que sua produção "contém fatos/ imagens/pensamentos verídicos", maliciosamente, Luana problematizou a formação docente baseada em modelos de treinamento e atualização, nos quais as/os estudantes conhecem tendências didáticas e metodológicas para aplicá-las em sala de aula. Ela também reivindicou espaço para conteúdos "autobiográficos", rejeitando tradições positivistas que desconsideram os saberes do cotidiano no campo da pesquisa e questionou porque textos escritos em "primeira pessoa" ainda causam rebuliço no campo acadêmico.

"Experiências A/r/tográficas" envolveu o resgate de vivências, a construção de um produto e/ou imersão artística e a reflexão crítica das/os espectadoras/es bem como, e inevitavelmente, das/os próprios investigadoras/es. O desafio de pesquisar, artistar e ensinar a partir de nossas vivências correspondeu a "investigações impregnadas de práticas não são apenas agregadas à vida de alguém, mas são a própria vida deste" (IRWIN, 2013, p. 28).

O enfoque nas narrativas pessoais legitimou - no âmbito acadêmico - experiências relevantes que ganharam novos sentidos quando refletidas. São experiências de vida em forma de re- 
lato que "desde uma perspectiva de conhecimento prático, narrativas e relatos são ferramentas de trabalho que os profissionais utilizam com frequência tanto pra dar sentido a sua experiência quanto para organizá-la" (PARDIÑAS, 2010, p. 23). Nos encontros em sala de aula buscamos transformar visualidades ao lidarmos "com a multiplicidade de sentidos, significados e usos dessas experiências, entendendo-as sempre como trincheiras de nossas subjetividades, de nossos contextos, parcialidades e, também, delírios" (MARTINS; TOURINHO, 2015, p. 137).

Eu estava inserida neste processo produzindo e expondo minhas histórias pessoais para entender a formação de professoras/es para questões de gênero e sexualidades. Assim como Conelly e Cladinni (2000), me tornei personagem vulnerável e sofri as erosões do processo que tentei problematizar. Pretendi que minhas histórias criassem, instigassem, provocassem, rasgassem e/ou fraturassem outras histórias.

Esta foi minha busca ao produzir a instalação "Tramações" na qual inseri fotos do happening "Como destruir o vestido" dentro de uma mala tramada com uma rede de elásticos. O happening foi uma proposta reflexiva, pedagógica e de imersão poética que problematizou discursos naturalizados sobre ser mulher. Durante quatro horas destruí publicamente o vestido de noiva que costurei e bordei. Neste momento, contei com a ajuda e interação de um grupo de amigas e de inúmeros pedestres que circulavam pela praia de Boa Viagem/ Recife, em março de 2015.

Envolvida em uma trama de significações sobre ser mulher, mãe e esposa, decidi materializar minhas dúvidas, inquietações e desejos de rompimento através da destruição de um vestido de noiva que costurei durante três meses. Foram meses costurando o sonho e o vestido do casamento para depois destruí-lo. Logo após destruir o vestido e postar as fotos nas redes sociais recebi muitos relatos de mulheres que sofreram algum tipo de violência de gênero atrelada à instituição casamento. Fiquei impressionada com o número de mulheres que também desejavam "destruir" seus vestidos de casamento.

Sentimentos desencontrados e discursos naturalizados sobre ser mulher instigaram a produçãode "Tramações". Para Louro (2007), discutir sobre gênero representa pensar sobre como o masculino e o feminino são constituídos e problematizar relações sociais consideradas "comuns" ou "normais". Ao contar, inventar e reinventar experiências estamos gerando processos de mudanças microfísicas, ao nível do pessoal/subjetivo, e possibilidades de transformações, diálogos e entendimentos 
sobre lugares que ocupamos nas redes de poder. Um processo emancipatório é desencadeado a partir da tramação de nossas histórias - e o que escolhemos contar - com o acontecimento em si e a interpretação do outro. Uma tríade que provoca, constrói sentidos.

Aguirre (2011) trabalha com aspectos da educação da cultura visual visando a um sentido emancipador. Fundamenta-se no princípio de que "tanto os estudos da cultura visual como suas aplicações vem trabalhando arduamente na identificação crítica das lógicas que regulam nossos regimes de representação" (AGUIRRE, 2011, p. 89) e amplia a questão afirmando que uma educação emancipadora não se restringe a conhecer e mostrar mecanismos de poder e posições hegemônicas, mas, oportunizar e promover mudanças tendo em vista que "a compreensão dos mecanismos de dominação não garante em absoluto a transformação das consciências e das situações" (AGUIRRE, 2011, p. 90).

Nesse percurso protagonizamos a produção de imagens que duvidam das maneiras normatizadas sobre como viver feminilidades e masculinidades. Interrogamos os sentidos sobre ser mulher/homem com os quais convivemos e, com isso, fraturamos formas de ver.

Giselle provocou uma destas fraturas ao retratar/legitimar algumas histórias e divindades femininas das religiões afro-brasileiras. O preconceito sofrido em uma parada de ônibus e o deboche de seus cabelos no metrô foram pontos de partida para pensar sistemas de representação e romper supostas atribuições sociais do feminino. Sobre sua formação profissional no curso de artes visuais, questionou o apagamento da mulher na história da arte e a ausência de discussões étnico-raciais nos âmbitos formais e não formais de ensino.

Rafael apresentou uma escultura em forma de cintos de castidade, uma masculina e outra feminina, dispostos em um manequim de costura, no qual foram alfinetados papéis com relatos de preconceito sofrido pelos visitantes da exposição, "problematizando o cinto de castidade enquanto arma branca tolhedora de autonomia e liberdade, tão quão o preconceito".

Somos ensinados sobre o que podemos fazer, responder, temer, gostar e considerar perigoso. Prazeres e desejos são autorregulados porque, mesmo sem um olhar vigilante, reproduzimos as normas comportamentais e as exigimos dos demais. Na teorização foucaultiana, poder é um conceito que não diz respeito especificamente à coerção e a repressão, mas, às relações de força nas quais estamos inseridos e, na maioria 
das vezes, estão ligadas as capacidades de governo, autogoverno e autorregulação.

Esse "poder disciplinar" (FOUCAULT, 1987) fabrica, molda e determina os sujeitos que passam a serem produtores de mecanismos de disciplina. As esculturas de Rafael foram especialmente desafiadoras porque trouxeram à tona discussões sobre o prazer, erotismo e desejo sexual em um contexto de normatização das vontades e dos comportamentos. Condutas ditadas, mantidas, vigiadas e refeitas foram colocadas em xeque pelo áudio de prazer e gozo - justapostos às esculturas - que impregnou o prédio, envergonhando e/ou incentivando alguns visitantes a interagirem através de relatos como vítimas de preconceitos. Para Rafael, constitui-se, também, como ação crítica e educativa que deslocou posicionamentos nas redes de poder:

\begin{abstract}
A instalação "Instrumento Humano Indispensável" registrou depoimentos de visitantes estimulados a relatarem suas experiências através da escrita desafiando a naturalização do preconceito e revelando como variados fatos e comportamentos presentes no cotidiano carregam conteúdo segregador e opressor. Registar as vozes daqueles que são "alvos" preferenciais da intolerância foi um exercício de deslocamento de ponto de vista, favorecendo a empatia com as diversas condições humanas e possibilitando a reflexão crítica sobre tais questões.
\end{abstract}

\title{
Possibilidades de "ver" e "ser visto"
}

Narrativas de professoras/es e estudantes apresentam potencialidades como textos pedagógicos, mas, muitas vezes suas histórias não são registradas, dificultando a continuidade de reflexões sobre o próprio processo de formação docente. Por isso, construir e registrar experiências pessoais e práticas educativas através de produções poéticas possibilitou circulação de ideias, autorreflexão, continuidade das discussões com outros grupos de professoras/es e estudantes, inovação nas práticas pedagógicas, protagonismo político e legitimação destes profissionais como produtores de conhecimentos e sua circulação nas redes de saber-poder.

Ao procurar possibilidades de qualificação docente para os enfrentamentos que vivenciava no cotidiano da escola e, posteriormente, para orientar estudantes em processo de formação, entendi que "as questões em torno dos gêneros e das 
sexualidades não envolvem apenas conhecimento ou informação, mas envolvem valores e um posicionamento político diante da multiplicidade de formas de viver e de ser" (LOURO, 2011, p. 62). Luana também direcionou seus entendimentos neste caminho ao dizer:

No campo artístico e, em específico, no contexto das representações femininas e do lugar ocupado pela mulher ao longo dos anos na História da Arte, os sistemas opressores se consolidaram e perduram até a contemporaneidade. Ser mulher e ter a oportunidade de desenvolver um projeto artístico que atravesse as questões de gênero me fez perceber a dimensão política da arte. Foi a esta dimensão que atribuí caráter educativo em "Pequenas Agressões". Pretendi valorizar uma experiência de compreensão humana, que corresponde, de acordo com Morin (2007), a um dos sete saberes necessários à educação do futuro. A compreensão humana "comporta uma parte de empatia e identificação, o que faz com que se compreenda alguém que chora, por exemplo, não é analisando as lágrimas no microscópio, mas porque sabe-se do significado da dor, da emoção" (MORIN, 2007, p. 54). No fundo eu desejei suscitar o diálogo sobre gênero, violência, feminismo e arte. Quando idealizei a concretização dessa proposta, imaginei pessoas se questionando, movimentando-se por dentro, reconhecendo-se e se (trans)formando na experiência visual.

Nossas "Experiências A/r/tográficas" possibilitaram protagonismos no processo de formação docente em artes visuais e, intimamente envolvidas/os e reconhecendo-nos nas experiências visuais, deixamos perguntas: como acontecem as discussões sobre gênero e sexualidades na formação das/os professoras/es de artes visuais? Como legitimar as narrativas de professoras/es no processo de formação docente? Como produções poéticas e narrativas assumem atribuições políticas no campo da educação da cultura visual? Quais possibilidades pedagógicas geradas por um processo crítico/narrativo e poético na formação de educadoras/es? Como socializar e comunicar nossas experiências a/r/tográficas em um campo de pesquisa e formação docente marcado pelas tradições positivistas? Jacilene cresceu "ouvindo que mulher nasceu pra sofrer. Se eu me machucava e chorava diziam que seria mole 
demais para parir". Como suas tesouras e facas podem cortar (com tensão) discursos naturalizados sobre ser mulher? Como os relatos de mulheres registrados por Luana e expostos através do lambe-lambe se tornaram ferramentas educativas e de combate a violência de gênero?

\section{Referências}

AGUIRRE, Imanol. Cultura visual, política da estética e educação emancipadora. In: MARTINS, Raimundo; TOURINHO, Irene (Org.). Educação da cultura visual: conceitos e contextos. Santa Maria: Editora UFSM, 2011, p. 69-111.

CONELLY,M.; CLADININ, J. Narrative inquiry. San Francisco: Jossey-Bass, 2000.

DIAS, Belidson. A/r/tografia como metodologia e pedagogia em artes: uma introdução. In: DIAS, Belidson; IRWIN, Rita (Org.). Pesquisa educacional baseada em arte: a/r/tografia. Santa Maria: Editora UFSM, 2013, p. 21-28.

EÇA, Teresa Torres. Perguntas no ar sobre metodologias de pesquisa em arte-educação. In: DIAS, Belidson; IRWIN, Rita (Org.). Pesquisa educacional baseada em arte: a/r/tografia. Santa Maria: Editora UFSM, 2013, p. 71-82.

FOUCAULT, Michael. Vigiar e Punir: nascimento da prisão. Petrópolis: Vozes, 1987.

IRWIN, Rita. A/r/tografia. In: DIAS, Belidson; IRWIN, Rita (Org.). Pesquisa educacional baseada em arte: a/r/tografia. Santa Maria: Editora UFSM, 2013, p. 27-35.

LOURO, Guacira Lopes. Gênero Sexualidade e Educação: uma perspectiva pós-estruturalista. Rio de Janeiro: Petrópolis, 2007.

LOURO, Guacira Lopes. Educação e docência: diversidade, gênero e sexualidade. Revista Brasileira de Pesquisa sobre Formação Docente, v. 4, 2011, p. 1-6.

MARTINS, Raimundo. Metodologias visuais: com imagens e sobre imagens. In: DIAS, Belidson; IRWIN, Rita (Org.). Pesquisa educacional baseada em arte: $\mathrm{a} / \mathrm{r} /$ tografia. Santa Maria: Editora UFSM, 2013, p. 83-95.

MARTINS, Raimundo; TOURINHO, Irene. Encontros com sensibilidades em saudáveis desequilíbrios da razão: atos e processos de aprender, pesquisar e ensinar. In:

(Org.). Educação da Cultura Visual: Aprender... Pesquisar... Ensinar... Santa Maria: Editora UFSM, 2015, p. 133-146.

MORIN, Edgar. Educação e complexidade: os sete saberes e outros ensaios. São Paulo: Cortez: 2007. 
PARDIÑAS, Maria Jesus Agra. Topografía crítica: el hacer docente y sus lugares. In: EÇA, Teresa Torres Pereira; PARDIÑAS, Maria Jesus Agra; MARTÍNEZ, Cristina Trigo; PIMENTEL, Lúcia Gouvêa (Org.). Desafios da educação artística em contextos ibero-americanos. EDIÇÃO: APECV (Associação de Professores de Expressão e Comunicação Visual), Porto: Portugal, 2010, p. 18-35.

TOURINHO, Irene. Metodologia(s) de pesquisa em arte-educação: o que está (como vejo) em jogo? In: DIAS, Belidson; IRWIN, Rita (Org.). Pesquisa educacional baseada em arte: a/r/tografia. Santa Maria: Editora UFSM, 2013, p. 63-70.

Recebido em: 08/03/16

Aceito em: 09/05/16 


\section{LUCIANA BORRE NUNES \\ lucianaborre@yahoo.com.br \\ Professora no Curso de Artes Visuais da Universidade Federal de Per- nambuco (UFPE). É doutora pelo Programa de Pós-Graduação em Arte e Cultura Visual da Faculdade de Artes Visuais da Universidade Federal de Goiás (FAV/UFG). Integrante do Grupo de Pesquisa Cultura Visual e Educação (GPCVE). Mestre em Educação (2008) pela Pontifícia Univer- sidade Católica do Rio Grande do Sul (PUCRS); especialista em Gestão e Planejamento Escolar (2006) pela PUCRS e graduada em Pedagogia (2004) pela Universidade Federal do Rio Grande do Sul (UFRGS).}

